See discussions, stats, and author profiles for this publication at: https://www.researchgate.net/publication/345262135

\title{
Business with Purpose and the Purpose of Business Schools: Re-Imagining Capitalism in a Post Pandemic World: A Conversation with Jay Coen Gilbert, Raymond Miles, Christian Felber,...
}

Article in Journal of Management Inquiry · November 2020

DOI: $10.1177 / 1056492620970279$

CITATION

1

3 authors, including:

Héctor O. Rocha

IAE Business School

37 PUBLICATIONS 910 CITATIONS

SEE PROFILE

Some of the authors of this publication are also working on these related projects:

Towards a Humanistic Theory of Organizing View project

Research Handbook of Responsible Management View project
READS

457

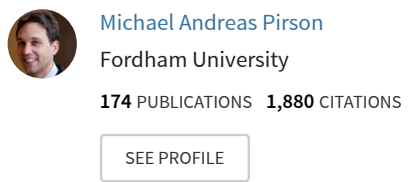


Business with Purpose and the Purpose of Business Schools: Re-Imagining Capitalism in a Post Pandemic World

A Conversation with Jay Coen Gilbert, Raymond Miles, Christian Felber, Raj Sisodia, Paul Adler and Charles Wookey

\author{
Hector Rocha \\ IAE Business School \\ Michael Pirson \\ Gabelli School of Business \\ Fordham University \\ Roy Suddaby \\ Peter B. Gustavson School of Business \\ University of Victoria \\ $\&$ \\ Carson College of Business \\ Washington State University
}

Forthcoming in the "Meet the Person" Section of the Journal of Management Inquiry

The final version is available at SAGE via: https://doi.org/10.1177/1056492620970279 


\begin{abstract}
The emergence of innovative business models suggests that the foundational assumptions of competitive capitalism are increasingly in doubt. Business schools, however, appear to be followers rather than leaders in this historical moment of social change. While consumers and businesses are experimenting with new models of capitalism, business schools have been slow to change. What role should business schools play in this emerging new era of purpose-driven capitalism and business with purpose? We explore this question in conversation with six global experts, three in academia and three in practice, who are leading this change. The experts conclude that business must serve the needs of humanity rather than the needs of business. Business schools, therefore, need to reduce their emphasis on how to make businesses more rational and efficient and should instead focus on how businesses can help address more fundamental questions of the human condition.
\end{abstract}




\section{Introduction}

The COVID-19 crisis has exposed serious flaws in the institutions of modern capitalism. Global supply chains have been slow to react to spiking demand for medical equipment. The pandemic has disproportionately affected the poor, contingent workers, and the elderly, and threatens to accelerate the pace of global inequality. The virus has also revealed the errors of decades of chronic underfunding of public institutions by governments elected on the promise of continually reducing taxes. Perhaps most critically, the virus has inverted the assumptive logic of neoliberalism which places economic interests at the base of our implicit hierarchy of needs and consigns health, related humanitarian needs, and, ultimately, happiness to the secondary status of epiphenomena. The COVID crisis fundamentally challenges the prevailing assumptions of corporate market capitalism, that is, profit as the fundamental purpose of business (Friedman, 1970), opportunism as the key feature of managers' behavior (Jensen \& Meckling, 1976), and competition as the key process for reaching prosperity (Porter, 1998). The crisis demonstrates that there are more profound ontological 'givens' than the right to earn profits. The global pandemic questions the prevailing assumption that a thriving economy will ensure social wellbeing.

These challenges hold serious implications for the role of business schools and management education. For some time now, business schools have been subject to considerable criticism for their failure to lead the process of normative change in a context where the ontological assumptions of capitalism have become increasingly suspect. For some time now, there has been a growing concern that management education places excessive emphasis on profit maximization at the expense of societal wellbeing and concern for the natural environment (Ghoshal, 2005; Pfeffer, 2005), that prevailing management theories and business school education actually reinforce negative social values of greed and self-interest (Wang \& Murnighan, 2011), and that 
business schools have been complicit actors in a long list of prominent corporate scandals (Podolny, 2009). Management education appears to have lost its soul and purpose (Bennis \& O'Toole, 2005; Khurana, 2007).

The quarantine response to the COVID-19 crisis has created the reflective space to revisit the core assumptions of business and management education. The crisis also appears to have granted us an opportunity to rethink the foundational institutions of capitalism. But what might be the purpose of business in a post-pandemic scenario? What would a post-pandemic business school look like? What might be the foundational values of a post-pandemic market system? We explore these ideas in conversation with six thought leaders and prominent innovators of both management education and business practices. Briefly they are:

- Jay Coen Gilbert (JC), the co-founder of $\boldsymbol{B}$-Lab a non-profit organization that promotes B-Corps and serves a global movement of entrepreneurs using the power of business to solve social and environmental problems;

- Raymond Miles (RM), Professor Emeritus and former Dean of the Haas School of Business at the University of California, Berkeley. Dr. Miles has been writing about management and organizations since the late 1950s, focusing on the intersection of managerial and national values, leadership styles and innovation;

- Christian Felber (CF) created the Economy for the Common Good in 2010, a social movement that advocates for a more ethical business model in which the wellbeing of people and environment replaces greed and profit as the primary goal of business achieved primarily through cooperation rather than competition;

- Rajendra Sisodia (RS) is the FW Olin Distinguished Professor of Global Business and Whole Foods Market Research Scholar in Conscious Capitalism at Babson College. He is also Co-Founder and Co-Chairman of Conscious Capitalism Inc. an organization that supports a global network of business leaders devoted to elevating humanity through innovative business practices.

- Paul Adler (PA) is the Harold Quinton Chair of Business Policy and Professor of Management \& Organization, Sociology and Environmental Studies at the Paul Mirage School of Business, University of Southern California and the former President of the Academy of Management the leading professional association of management scholars. 
- Charles Wookey (CW) is the founder and CEO of Blueprint for a Better Business, an UK charity that challenges the foundational assumptions of business and what motivates people in an effort to redefine the purpose of business and its relationship with society.

Collectively, these individuals have led an emerging movement dedicated to redefine the purpose of business and the nature of market capitalism. A unifying assumption of their individual projects is the shared belief that the challenges of capitalism are not insurmountable obstacles but, rather, require a creative restatement of the core values and purpose of business in society. They also each share a unifying assumption that business schools play a pivotal role in legitimating this change.

We engaged these innovators in conversation around the broad question of how we might "re-enchant" (Suddaby, et al., 2019) market capitalism and the role that business schools might play in that process. These conversations occurred before the COVID-19 crisis. However, as is so often the case, reading these comments through the lens of the current crisis brings added poignancy and meaning to their insights. The conversations were conducted via email exchange. The interviewees responded individually to our questions and formed their responses independently of each other. We present only parts of their responses given space limitations.

We acknowledge, with humility, the critique raised by our editors that these six innovators are exclusively males, and are drawn mainly from elite US institutions (Christian Felber and Charles Wookey being notable exceptions) and that their comments and critiques reflect a somewhat unique and privileged perspective, both on market capitalism and business schools. Our selection of interview subjects, however, are not intended to represent all varieties of capitalism (Hall, 2015; Whitley, 1999) nor all manifestations of business schools. Rather, they deliberately reflect contrarian voices that have emerged from the US which is the leading market economy in the world and, since the end of the Second World War, is the leading disseminator of management knowledge and practice globally (Gopinath, 2018). As such, our key informants offer somewhat 
surprisingly nonconformist views from the 'belly of the beast'. We also acknowledge that the issues we touch on are not new (e.g. Augier \& March, 2007). However the COVID crisis has placed these issues and their consequences in sharper relief.

We also note, with deep sadness, that the interview with Raymond Miles was conducted shortly before his passing on May 13, 2019 and that his comments here may constitute some of the last thoughts on management education, business schools and the challenges of capitalism of an outstanding scholar and visionary management educator.

\section{The Interview}

\section{How to solve the crisis of capitalism}

The capitalist system is under siege. "How to fix Capitalism" (Harvard Business Review), "Capitalism 2.0" (Drucker Conference), and "Capitalism into Question" (Academy of Management Conference) are just some headlines from prestigious organizations, academics and practitioners that highlight the crisis. Are we witnessing the fall of a system to give raise to a new one? Could we find the solution within the very capitalist system, making some adjustments, or should we look for new assumptions to start anew?

RM: Capitalism is under siege, and in my view, "rightly so." Executive pay is at astronomical levels, illegal firm practices abound; and the rich nations in the global economy enjoy the fruits of the labor of the less fortunate, underdeveloped economies. Adam Smith was right to be worried about potential abuses of the system he championed and he had no way of imagining the scope of the ethical challenges possible within and among globally operating superfirms. Of course this is not the first time capitalism has demonstrated its dark side. Many of today's firms are only repeating the behaviors of their predecessors in the latter part of the $19^{\text {th }}$ century and in the 1920 s.

We are entering a period that is likely to produce major reforms that will at least partially restrict the most egregious corporate behaviors. However, barring a major collapse of the global economy we are likely, and rightly, in my view to rely on the demonstrated superiority of marketbased economic systems within which firms can operate at the edge of the law if they so choose. We cannot correct all unethical corporate contrivances, but we can make them socially unacceptable and subject to righteous public scorn. 
More importantly, we have the potential in the academic community to demonstrate that ethical corporate activity not only is and has been historically, the basis of long-term corporate success, but we can demonstrate that trustworthy behavior is the key to economic success in the economy.

The most creative modern firms are already demonstrating how successful firms will operate tomorrow and across, at least, the next few generations. We are well into an age in which knowledge-driven innovation will be the key to corporate success. Today's and tomorrow's firms have potentially unlimited opportunities to create wealth by innovatively utilizing rapidly expanding knowledge to create a currently barely imaginable array of products and services, capable of taking the global society to new levels of wellbeing and happiness.

In order to take this next step, firms must seek to emulate the laboratories and classrooms where the knowledge that is driving and will possibly drive the global economy is being created. Knowledge, in the best of those laboratories and classrooms, is knowingly and trustworthily shared, viewed by all involved as the common gold to be mined to the benefit of all mankind. In today's most impressive firms, the ethics of knowledge creation are driving knowledge-sharing processes that are enabling massive, continuous innovations. Moreover, the most progressive firms are rapidly creating communities of firms across complimentary markets within which knowledge can be shared and innovations can be brought to market across firms to the benefit of all. After decades of indulgence of personal and market privilege, many executives and their firms are hesitant to engage in collaborative innovation across firms.

JC: Rather than a fall, I think we are witnessing the evolution of capitalism. Current law requires corporations to prioritize the financial interests of shareholders over the interests of workers, communities, and the environment. That old conception of the role of business in society is at best limiting, and at worst destructive. To create true change, businesses must create value for all stakeholders, not just shareholders. By creating greater infrastructure - standards, corporate forms, incentives - we can use the power of business to create real change.

PA: I think it is urgent that we leave capitalism behind and build a democratic-socialist economic and political system — one in which we can work together, democratically, to manage strategically our productive resources in order to resolve the big challenges we face as a civilization. Why such a radical change? We face challenges that are not resolvable so long as we 
maintain a basically capitalist form of economy, where profit-seeking firms employ wage labor and compete in markets.

I see six such challenges. First, we suffer from persistent economic irrationality in various forms: obscene levels of income and wealth inequality, periodic economic and financial crises that throw millions out of jobs and even out of their homes, an economy that produces an extraordinary amount goods and services we do not need and too little of what we do.

Second, there is widespread anger and frustration generated by pervasive disempowerment in the workplace. Most of us have no real "say" or "voice" at work (Pew, 2016). This workplace disempowerment reflects the fact that in a capitalist system firms employ people in exchange for wages. In such a system, employees are only means, not ends in themselves - they are "human resources" deployed by the firm to achieve profits and growth.

Third, we are creating ever more stress on the planet's ecosystems. Today, humanity is using the planet's natural resources nearly $60 \%$ faster than they can be replenished (WWF, 2014). The environmental crisis is due primarily to the fact that in any capitalist system, market competition leaves firms no choice but to focus on their own profitable growth and ignore environmental externalities, and they therefore often behave irresponsibly towards the natural environment.

Fourth, we are experiencing a set of interacting social crises in our gender and race relations, in our families, neighborhoods, cities, and regions, and in our systems of criminal justice, healthcare, childcare, eldercare, housing, and education. This social crisis is progressively corroding the social fabric of every capitalist society.

[Fifth, we need] aggressive government action to regulate the business sector; So long as we live in a society whose income and wealth are produced by a capitalist economic core, government must depend for its tax resources and its political legitimacy on the continued profitability of that core.

Sixth, we live in a world that cries out for international collaboration to address so many problems - climate change, wars, the risk of nuclear conflagration, the persistence of abject poverty, , to name just a few-but such collaboration is stymied by international rivalries. Their root cause lies in the fact that the governments of capitalist nations must support the interests of their own national businesses, which compete with those based in other nations. I don't see how we resolve any of these six major crises so long as our economy remains capitalist. 
CF: Both questions depend on the very definition of capitalism. The literal definition of capitalism I use is an economic order in which capital is the highest value and its increase the highest goal next to other values and goals that are subordinate. A "pure" capitalistic system has never existed anywhere, so I am talking about what is identified as "US corporate capitalism" or "globalized financial capitalism"...[The] legal structures [of capitalism] have to be transformed gradually and in the long term through democratic processes. I introduce this option as "sovereign democracy" in my reform proposals. Thanks to sovereign democracy the people could change every single ... element of the capitalistic order and transform it into an "economic" order (in the meaning of Aristotle: "oikonomia" vs. "chrematistiké"). In a true "economy," economic initiative, private firms, markets, money, and private property still exist, but, in contrast to capitalism, there would also be the obligation for all companies to do a common-good balance sheet; incentives for good performances for the greater good; a size limit for companies and a global fusion control; minimum (living) wages and limitations for income inequality; limitation for the accumulation of private property of individuals; restrictions for legal persons: compulsory entry in a lobby register, country-by-country tax declaration, and prohibition to finance political candidates or parties; tax cooperation between countries with free movement of capital;

Such a system in which real values (such as life quality, wellbeing, and the common good) are the overarching goals of economic activities.

RS: Our system of capitalism is based on Adam Smith's profound insight that freedom leads to prosperity. In other words, societies rooted in individual freedom, where individuals are free to pursue their own self-interest and use that to meet the needs of others, will result in most of the needs of most of the people being met by other people, rather than by the government. The idea of pursuing one's self-interest is deeply rooted in Enlightenment values such as freedom and individualism.

However, Smith had also addressed another aspect of human nature in his earlier book, The Theory of Moral Sentiments. This was about the human need to care, which is as powerful if not more powerful than our drive for self-interest. Unfortunately, that message was largely ignored in the years and decades and centuries to come, and the institution of capitalism developed on a limited view of human motivation. The system was heavily rooted in the masculine energies of freedom and self-determination, while completely lacking the counterbalancing energy of the feminine, which is rooted in inclusiveness and caring. As a result, the healthy masculine energy 
over time increasingly mutated into hyper-masculine traits such as domination, aggression, excessive competition, winning at all costs - a mentality that treated business as a form of war.

So we don't need to replace capitalism; we just need to make it whole. We need to bring in the missing parts, a major one being the feminine. To be whole is to be healed and healthy. A business that is simultaneously rooted in caring for others as well as pursuing one's own selfinterest will spread, flourishing in the world in a far more powerful way, and will not cause suffering in people, the planet, or in other species.

True wholeness also requires two other qualities or energies: what I refer to as elder energy and child energy. Elder energy refers to meaning and purpose. Child energy is about joy and creativity. Businesses need to manifest all four of these to be fully healthy and whole. I believe this is what we should strive to realize by evolving capitalism in these ways.

CHW: When people use the word "capitalism" they often mean different things. In the UK context it creates an ideological divide, and easily generates more heat than light. A senior business leader who was strongly supportive of our work at Blueprint advised us at the outset to avoid using the word. It was very helpful guidance. The question we ask is: what is the role of business in society and how is that changing?

We live in world where globalization, technology, and weak anti-trust law is creating strong concentrations of monopolistic power. We also see the lack of countervailing power on what major companies do because of relatively weak government, weak consumer pressure, and weak unions. Taken together with the rapid rise in public concern about social inequality, job insecurity, and environmental threats, there is without question a growing societal demand for a new contract between business and society.

\section{How do we cure competitive markets?}

Which are the features of an economic and social system with human, social and environmental face, in addition to foster material prosperity? Which are the features of an economic and social system with human, social, and environmental face, in addition to fostering material prosperity?

RM: As suggested, highly successful firms in the coming decades will succeed by demonstrating that they can trustworthily collaborate to utilize knowledge across market lines. Today, many firms make only limited use of the knowledge distributed across their own 
departments and levels - knowledge that could readily be used to enhance product and service designs and performance and the efficiency of their production. Despite repeated demonstrations of the willingness and ability of organization members to generate, share, and utilize knowledge in the process of innovation, firms persist in searching out and utilizing only a fraction of their innovation potential. For many firms, innovation planning and utilization is limited by the scope of their current and easily identifiable potential market. However, such firms frequently sit beside firms addressing related markets where that unutilized knowledge might be wealth generating. Across many current and emerging industries, the clear challenge facing modern firms is how to utilize the surge of wealth-creating knowledge that demands collaboration within and across firm utilization.

JC: We need a system where businesses enjoy the freedom to pursue a broader set of objectives. They need the legal protection to create value for society, not just for shareholders. There also must be higher standards of accountability and transparency so that investors, consumers, and policy makers can trust that these companies practice what they preach.

PA: If we are to overcome these crises and create the world that humanity deserves, we need to change the way enterprises make decisions about investment, products, and work. These decisions need to be guided by the needs of people and the planet - not just by profitability considerations. They need to be made democratically, informed by deliberation and debate among all the relevant stakeholders - not made by CEOs and boards of directors doing the bidding of private investors. Moreover, to deal effectively with the economic, social, and environmental externalities of enterprise-level activity, we must manage society's productive resources at the region, industry, and national levels - not leave the outcomes at these higher levels to be determined by the blind process of market competition among enterprises.

To make this happen, we need to replace private ownership of enterprise with socialized, public ownership. Once our productive resources are under socialized ownership, we can decide democratically how to manage those resources strategically to overcome the six crises effectively and equitably.

This socialist strategic management process must be democratic. Not only because we value the principle of equality, but also because, in our post-industrial era, progress requires democracy. Authoritarian socialist planning may have been effective in forcing feudalistic Russia and China rapidly into the industrial age, but it came at a terrible cost. Today we can tackle the 
crises we face and assure the progress we need only if we mobilize widespread creative problemsolving at every level in both our enterprises and our political sphere. Democracy is an essential precondition for that active engagement.

CF: This is a meta-limit for all economic activities. Scarce resources (e.g., biological resources, soil fertility, biodiversity) need to be carefully protected and used. Inequality is held limited thanks to "balancing feedback mechanisms" in income, property, inheritances, or the size of companies. A global fusion control exists as well as a lobby register; free movement of capital is firmly linked to transparency and full fiscal cooperation. The first goal of companies is a noble purpose such as contributing to wellbeing and the common good, success is measured accordingly (e.g., with a Common Good Product replacing GDP), a common good balance sheet (superordinated to the financial balance sheet) and an ethical risk assessment (super-ordinated to a financial risk assessment in investments). Fundamental values are known, respected, and enhanced in all parts of the economy. There is plurality of properties-public property, social property, private property, commons, no-use rights (nature), and no-property and no-use-areas (protected nature). All types of property meet limits and conditions. No type prevails over others. Decisions on the design of the economy and economic policy are deeply democratized and free of lobbying and technocracy, or supposes value-free expert decisions.

RS: The current capitalist system is overly anchored to the financial side. If the only purpose of a business is to make money, the only stakeholder that really counts is investors. But when a business has a purpose separate from making money, as all conscious businesses do, then it is critical to take into account the full commitment and wellbeing of all of the stakeholders of the business. A shared purpose and shared core values bind the stakeholders together, so that they no longer operate at cross purposes. Stakeholders include society, partners, customers, employees and their families, investors, communities, and the environment. Conscious businesses seek to create positive impacts on all of the stakeholders through all of the decisions. They recognize that there is no win without a win-win.

CHW: A good way to characterize the challenge is the need to move from an economic system optimized for growth and profit to a system optimized for human wellbeing and a sustainable ecosystem. What we find is that the senior business leaders we engage with recognize this scale of challenge and the need for a transformation of business in these terms. It gives a clear 
context for what the true challenge of being a purpose-led business - which is to be an enabler and not a blocker of this system shift.

This is a transformation that requires structural changes in law and regulation, capital market reforms, and many other things. But there is also something beyond law and regulation. The market never exists in a pure state. It is always a social and cultural construct, and the ideas that have dominated thinking over the last 40 years in the US and UK context need to change. One is that the purpose of business is to maximize profit. The other is that people, at least for the purposes of work, are best assumed to be self-interested and motivated by money, status, and power. These two ideas taken together combined with agency theory have contributed to a double disconnect: a disconnect between business and society when in pursuit of maximizing profit businesses have externalized social and environmental costs; and more profoundly a disconnect in the human heart if people feel part of their humanity is left at the door, and they are not respected or fulfilled through work. So, a fundamental aspect of the systemic problem is at the level of ideas - how and whether we can reframe the role of business as a social practice in a marketeconomy founded on respect for human dignity and oriented to serving the common good of society — alongside the public and voluntary sectors.

\section{How do we humanize the corporation?}

A small but growing number of scholars agree that profit maximization is unnatural and that the mission of a company is, by its very nature, at the intersection of the human, economic, social and ecological dimensions. Do you agree with this assertion?

JC: B Corporations are a lively response to this question. More than 3,000 leading businesses from 150 industries and 71 countries have earned B Corporation certification (from iconic sustainable businesses like Patagonia, Natura, and Ben \& Jerry's to next-generation social enterprises like Etsy in the US and d. light in emerging markets). B Lab provides this emerging marketplace with a North Star of companies that have met the highest standards of social and environmental performance, accountability, and transparency. We hope to inspire all companies to compete to be not just the best in the world but the best for the world.

CHW: Why does any company exist? It's because people come together to do something they could not do by themselves. At the heart of a business is a social organization, a series of human relationships. Most businesses bring people together to solve a problem, meet a need and 
thereby make a profit. Profit is fundamental to business but is best seen as a necessary condition and outcome of pursuing a purpose that benefits society. Of course, some people are in business just to make money. It's a choice, but it is not the only choice, and an available alternative exists. The focus on maximizing profit as the purpose of business has had a profoundly distorting impact on both business and society. It has distorted what companies do, and legitimated the denial of a wider social responsibility. In the extreme, as we saw in the financial crisis, the narrow pursuit of profit as an end in itself undermines the very basis of trust in the market on which all profitable activity depends.

Once we step back from the partial view of the company as a nexus of contracts to see it as a series of relationships, then from a human point of view the purpose of a company acquires a much richer and fuller meaning. Relationships with customers, suppliers, communities, employees, and the ecosystem are no longer simply instrumental to maximizing profit, but rather all of them are constitutive of the character of the company.

In UK law it is not the duty of a company director to "maximize" anything. In fact, their job is to balance, and to make decisions that keep the company true to its purpose. Blueprint's view is that a good corporate purpose starts from the human perspective, recognizing that each person is a "someone not a something," and seeking to create shared (common) goods through the quality of relationships it forms internally and externally, and seeing the economic and environmental aspects of business life in an integrated way as dimensions of a human system.

\section{What role has competition played in the crisis of capitalism?}

Is collaboration more important than competition to foster innovation and social progress? How collaboration and competition co-evolve?

RM: We have argued that the emerging arena of competition will be science and technology based and will cut across most current market lines. This new competitive world is being driven by collaborative research within and across scientific disciplines. Thus firm-centered research and development departments driven by existing firm market vision are inherently insufficient.

What we envision is that the new competitive challenge for many if not most firms will be the breadth of the arena of innovation that they address. Both the pace and the breadth of change is likely to increase in most product and service markets, as the modern world of mobile 
communication is illustrating, and is probably not addressable within a single firm. Clearly, the emergence and expansion of modern apps communities demonstrate both the pace and breadth of current and potential innovation. The new measure of competitive achievement for the typical firm will be the pace of innovation they pursue and the collaborative imagination with which they pursue it.

PA: Collaboration and competition both have their place in a dynamic capitalist economy and in the entrepreneurial process. But I don't see how any combination of cooperation and collaboration can resolve the big crises we face so long as these mechanisms operate within the capitalist economic framework.

I would add that in our capitalist economy, collaboration and competition do sometimes coexist, but only very uneasily. Yes, we see 'co-opetition' among peers in some industries, and we see some firms orchestrating supplier forums in which competing suppliers are encouraged to work together to share innovations. But it is naïve to ignore the general pattern, where the pressures of profitability and market competition tend over time to corrode collaboration.

In the socialist system, it will become far easier to bring enterprises together, since they will be under common, socialized ownership. In these conditions, competition will have far fewer negative effects and will coexist far more easily with collaboration.

CF: There can be free enterprise and an attitude of systemic cooperation. If companies do not act against each other, but strive for the same overarching goal - the wellbeing of all citizens and consumers, the common good, and try to find the best solutions for achieving this goal together - then companies actually do what the word "competition" literally means: to search together for the resolution of scarcity. Competition comes from the Latin words "cum" and "petere" and means "to search together". If companies searched for their own benefit against other companies, that would by definition be counterpetition ("contra" and "petere"), the opposite of competition.

RS: As with all polarities, we need a harmonious blending of competition and collaboration. Both are essential for the healthy functioning of society. Companies should think of their competitors as stakeholders from whom they can learn. Such an orientation allows for the growth and evolution towards higher states of functioning for all the entities. When there is alignment at a purpose level, competitors can start to be seen as fellow travelers. Companies such as REI, Patagonia, and L.L. Bean, have a shared purpose of safeguarding the environment and 
connecting people with nature. They thus view each other as friendly rivals traveling the same road, rather than as bitter enemies to be undermined and vanquished.

CHW: If you start with the idea that a business is a social organization, and that people are naturally relational, then collaboration is fundamental. When people act beyond self-interest and are genuinely seeking to work together to solve problems and meet needs, common - sharedgoods are created, which generate sustainable value for the business. In economic terms, the opposite of competition is not collaboration. It is a monopoly or a cartel. Fair and efficient markets need healthy competition. But they also and more fundamentally depend on collaboration, which creates the human goods that enable businesses to flourish as social organizations. The problem is that too much focus on competition reinforces a partial view of people as purely self-interested and we easily forget and undervalue the quality of human relationships, and think of people as mere means to business success.

\section{How might we redefine managers and entrepreneurs?}

It seems that a new system and corporation requires a new type of entrepreneur and manager. What are the key features an entrepreneur and a manager should have to match the new social and corporate challenges?

RM: The willingness to trust and to behave trustworthily - this is the challenge of the era of knowledge-driven innovation. Trust and trustworthiness are societal values, essential, ultimately, to the survival of humankind. Many leaders of many leading economies have minimized these values and encouraged firm-serving behaviors that violate them. Firm success in the emerging era will be, we believe, dependent on the judgment of potential collaborators as to its trustworthiness.

PA: In the democratic socialist system I envisage, we would need both entrepreneurs and managers, but they would play somewhat different roles than they do in capitalism today.

Start with entrepreneurs. A socialist economy would create far more opportunities for creative entrepreneurship than capitalism affords. Average weekly work hours would be significantly reduced because our socialist economy would eliminate a host of unproductive activities - e.g. insurance intermediaries, advertisers trying to make us buy more stuff, stock brokers and investment bankers, and lawyers and courts dealing with commercial conflicts — and this would free up time for entrepreneurial activity for many more people. 
And some of it would happen in independent entrepreneurial ventures. Whereas today's venture capitalists invest only where they see a good chance of multiplying the value of their investment by a factor of at least ten over three to five years, our socialist public industrial banks would be less greedy, and they would base their investment on the proposal's potential impact on the wellbeing of people and the planet. If these ventures prove successful and grow beyond a minimum size threshold, they would come under the new society's requirements for cooperative ownership and worker voice. But their founders and workers would have an easy "exit strategy" by attracting a take-over by one of socialized enterprises.

Whereas in a capitalist system this entrepreneurship process is associated with the personal enrichment of the founders and their venture capitalist investors, in a socialist society, entrepreneurs would be rewarded with far more modest monetary rewards but ample social recognition (Collins, Hanges \& Locke, 2004). In this socialist system, enterprises would still need managers - workers who specialize in coordinating and leading the work of others.

CF: First, she or he has to acknowledge that a company, which is a legal person that is created by society and thus has to obey a meta-objective or framework defined by the same society (to serve the common good) within which the company is "free" or allowed to serve also the purposes and needs of its (private) initiator(s. Second, the same values that are agreed upon by the society also hold true for the company. For instance, if the society is a democracy, the company cannot be a dictatorial or radically hierarchical organization. Third, constitutions protect solidarity and social cohesion, companies cannot counterfeit against each other, but meet in a cooperative spirit. It is not about being better than others, but doing something meaningful helping each other. Within the company, good leaders are first and foremost servants of the greater whole. Managers should help everyone else to fulfil the company's purpose and establish rules and processes that enhance the alignment of all activities with the company's purpose and bottom line. Finally, they cannot take hundreds or even thousands of times more money than what the average employees earn, but limit inequality at a reasonable level.

RS: The most essential element is a commitment to a higher purpose. Every company needs to have one, and every leader needs to be highly motivated by that purpose. In addition, entrepreneurs and leaders need to be whole people, who simultaneously embody the four kinds of energies we talked about earlier: the masculine or father energy of freedom and achievement; the 
feminine or mother energy of caring and inclusiveness; the elder energy of wisdom and meaning; and the child energy of joy and creativity.

CHW: What I find very exciting is the confluence of thinking. Whether you start with the wisdom traditions - Greek philosophy and the teachings of the great faiths — or if you start with empirical evidence in positive psychology, or recent research now in neuroscience, you end up in the same place. Money matters but for most people three other things are more fundamental— the quality of relationships, the desire for meaning and fulfillment through work, and the opportunity for autonomy, development and mastery.

\section{Are profits the only motive?}

The dominant paradigms at the academic and business levels assert that entrepreneurs and managers are profit-driven. Do you think that it is just a paradigm or it belongs to human nature? How do you think the formation of the new leaders should be in case it is just a paradigm?

RM: Profits are an outcome, not the purpose of corporate behavior. The purpose for which corporations were created is that they are an efficient and effective way to create societal (and corporate) wealth through the production and distribution of goods and services.

Many of the most successful entrepreneurs and managers I have known were driven by the joy of creation and service to humankind.

JC: Quite simply, more people are motivated by meaning than by money. In fact, as Millennials reach $50 \%$ of the global workforce, business leaders seeking the best talent ignore this simple truth at their peril.

And it's not just Millennials. Rick Warren's Purpose-Driven Life (Warren, 2002) is the best-selling nonfiction hard cover book in history (32 million copies). It doesn't take much effort to make the connection that if we want to lead purpose-driven lives, then we ought to find purposedriven businesses to work for, buy from, and invest in - and if we can't find one that inspires, then build one. B Corps makes it easier for all of us to do that.

A growing number of business leaders would agree that the purpose of business is to create a shared and durable prosperity. Said another way: to create high-quality jobs and to improve the quality of life in our communities. The words shared, durable, and quality are not captured in profit and loss statements, balance sheets, or cash flows. They are not (yet) priced into the market.

PA: In a capitalist society, managers and entrepreneurs are forced to prioritize profits. 
This has nothing to do with human nature, but the reality of capitalism imposes itself on us all. If cutting quality and short-changing the customer is what it takes to stay in business, that's a reality you can't simply ignore.

Unfortunately, business school faculty seem often to turn necessity into virtue, and we have many colleagues who preach a doctrine of market fundamentalism that pretends that profit can function effectively as a single objective function for the firm. This encourages a greed mindset in our students.

CF: Nothing "belongs" to human nature in the meaning of that human natureoblige us to a certain moral behavior. Human nature gives us the freedom to behave in virtually all kinds of ways, but neither pushes nor forces us to do it. Why should profit-seeking be part of the human condition? Of course, we can do it - like killing — but we don't have to do it and it is also not a basic need. No human person needs money, capital or profit, these are habits, beliefs, patterns, culture in its worse sense.

The formation of leaders of an economy for the common good would display the core elements of the new paradigm, which are: Ethics is the base of economics, not something additional or even hindering. Companies have a purpose, they serve the common good; capital and profit are just means. Humans are not "resources", but persons with dignity. Their wellbeing is the highest goal of economic activities. The ecological impact shall be the least possible and respect the biophysical boundaries of the planet. The organization has to respect the democratic state of law that it created and allows to operate and should not undermine itbut rather strengthen it.

RS: This is absolutely a paradigm, and a tragic one at that. It has become self-fulfilling, because this is what people are taught in business school or by their mentors in business who have been deeply rooted in the paradigm. Human nature is deep, rich and complex. It certainly includes self-interest, but as we have written above, it also includes many other dimensions. Businesses are akin to people; organizations consist of organisms. We need to allow for the fullness or wholeness of each business to be expressed.

Since it is just a paradigm, we must cultivate leaders who are able to see this and shift to a better paradigm. We need a more human story of business, one that is more deeply rooted in truth and love. Leaders who are not themselves whole human beings cannot lead a business in the ways our times call for. Our summary phrase for such leaders is "the wise fools of tough love." They fully embody and can manifest all four of those qualities: wisdom, which reflects the adult or 
parent or elder or divine self; foolishness, which reflects the awakened inner child; toughness, which is the mature masculine; and love, which represents the mature feminine. Once they are whole, they need to have the discernment to know which of these qualities are most needed in a given situation, and the flexibility to be able to show up in that way, while remaining true to who they are.

CHW: As mentioned in my previous answer, both the wisdom tradition and neuroscience show that people have motivations beyond economic gains. There is no doubt that some entrepreneurs and managers are strongly motivated by money, but what is really important for the formation of new leaders is to show examples of leaders motivated differently, so that this assumption is challenged, and people are able to explore these deeper and richer sources of human motivation in themselves and others.

\section{Is greed good?}

We have seen the required changes at the level of society, of companies, entrepreneurs and managers. At the level of people, the dominant economic paradigm asserts that all of us are driven by self-interest. Do you think that it is just a paradigm or that it belongs to human nature? What are the necessary changes we as consumers, employees, investors, providers and members of a community should undertake to meet the new challenges mentioned above?

RM: Having been born in the early days of the Great Depression, I grew up seeing people helping people across business, social, and institutional boundaries. To be selfish was to be sinful. Similarly, as society went from depression to global conflict, the heroic image was that of the person risking injury or death for the benefit of crewmates or society at large. Thus, from the executives who worked for $\$ 1$ per year, to the women who labored heroically to build planes and ships, people heroically behaved in responsible, other-serving ways. Thus, I cannot believe that behaving in a consistently self-serving way is part of human nature. Self-focus, as the psychologist Abraham Maslow suggested, is something a healthy human learns to control or refocus as they progress through life's stages from infancy, through adolescence, into increasing maturity.

JC: A full life is a life of service to something more than oneself, whether that something be family, friends, community, the environment, society, or future generations. By restricting our economic life to the pursuit of purely selfish and material ends, we restrict our own development 
as humans by diminishing our capacity to serve others. By creating businesses that are free to pursue a higher purpose we unleash the full creative power of humans to use business as a force for good, addressing our most challenging problems from poverty alleviation to environmental restoration.

B Corps and benefit corporation laws help us work, and live, on purpose. Sometimes that will also maximize profits, sometimes it won't, but when it's all said and done, that isn't the measure of what matters.

PA: Since I am defending a socialist alternative, let me rephrase your question with a sharper edge. Socialism has long been associated with collectivism. Indeed, an effective democratic-socialist economy would require widespread acceptance that what's best for the whole enterprise and for the whole society should weigh substantially in our individual choices. But would this collectivistic ethos undermine the individualism that has proven so potent under capitalism in motivating effort, creativity, and innovation? Unless socialist society is willing to forego those benefits, it would need to cultivate both collectivistic and individualistic motivesand that seems to pose a dilemma.

I have been impressed by some of the "high road" firms that seem to be able to develop employees who are committed both to implementing the agreed-upon plan and to contributing novel ideas in the development of that plan, to performing their routine tasks efficiently and to contributing creative ideas for improving their performance. They do this by nurturing an ethos of interdependence - creating a basis of motivation that goes beyond both independence, based on individual self-interest, and dependence, based on the approval of the collectivity.

This synthesis of individualism and collectivism in an ethos of interdependence would flourish in a democratic-socialist form of society.

CF: Same here. People can pursue their self-interest, but they don't have to. Humans can be other-oriented or common good-oriented. All economic actors should take into consideration all consequences of their economic decisions. Everybody, in any role, shall bear in mind the common good. This is what many constitutions mandate: "Property obliges. Its use shall at the same time serve the common good", says the German Fundamental Law for instance.

In order to measure this orientation and achievements, I recommend a common-good exam (ethical risk exam) for investments and loans, a common-good balance sheet for companies (500 companies have already done one) and a Common-Good Product—instead of GDP_-for national 
economies. Instead of measuring and aiming at financial indicators and parameters, which would be a "chrematistic" approach and practice, (true) "economies" would aim at and measure the increase of the common good.

RS: I have addressed this question above. It is a grotesque caricature to suggest that we are only driven by self-interest, even if economists have tried to finesse that by broadening the definition of self-interest. Purpose, love and joy are all powerful aspects of human beings.

CWH: Our view is that self-interest is important but it is only a partial description of human motivation. A fuller more realistic account, which draws on both wisdom traditions and empirical science, recognizes that we are also relational, and that our fulfillment as people is bound up with that of others, exemplified by what happens when people become true friends. We are all individuals with self-awareness and self-interest. But if we only see people in this way, how can we each relate to others except as a means to achieving our own goals? We need to add to this partial view the relational dimension. People share their hopes and desires, which if satisfied together leads to fulfillment. Modern culture has celebrated the autonomy of the individual, and along the way we have neglected this fundamental relational aspect of what it means to be human. The most important foundations in any culture to nourish and sustain this fuller and richer sense of what it means to be human are the family and education. A profound cultural challenge to the business world is the extent to which it reinforces and exaggerates this partial view of what it means to be human. So the transformation needed in the business world is to become a social actor in society, committed to building up a sense of the wider common good.

\section{How can business schools rediscover their purpose?}

What would be the role of Business Education and, specifically, Business Schools, in fostering a change of paradigm at the personal, organizational and social levels?

JC: There are three aspects to my response to this question. First, business schools can deepen the personal capacity of its students to affect change. As millenials increasingly demand a sense of purpose at work rather than profit-maximization of the organization, the emerging workforce needs assistance translating these ideals into practice. Business schools can uniquely equip future leaders with the frameworks, networks, and skills to create a shared and durable

prosperity for all, empowering individuals to live lives of service through business. Second, they can provide curriculum to prepare the next generation for the impact economy. As we experience 
the evolution of capitalism in the marketplace, the way business is taught should evolve on campus, both in what is taught and how it is taught. Dynamic business education prepares the next generation of leaders to consider, if not prioritize, the interests of workers, communities, and the environment to harness the power of business as a force for good. Third, they can use their influence to signal the shifting role of business. As the definition of success in business expands to include material societal and environmental value creation, the influence business schools have in shaping the understanding of business' role in society cannot be overstated. Business schools can accelerate mainstream adoption of the change by turning this definition of success into the new 'business as usual'.

RM: This is a tough question and I can only point to the two periods since Adam Smith (1776) when business got it right - the early period of business in the US prior to the Civil War and the immediate decades after the Great Depression and WW II. Business education got it right in those periods by using the best examples of firms and business owners. In the early days of business growth, many of the inhabitants had come to the new world to escape the excesses of the industrial revolution and both firm owners and employees were sensitized to the consequences of excessive competitive behavior. In the 1950s and 1960s the human values and experiences from the Great Depression and WW II were fresh in the mind of the populace and government leaders. The depression demonstrated the benefits of sharing at work and with the fruits of that labor. After WW II, the GI Bill brought former military personnel with their values shaped by war time into firms and the Marshall Plan and the Japanese recovery program brought those values to Europe and Asia.

Business education brought these insights to business students in business schools as well as the broader population. Through the 1950s and 1960s, business professors demonstrated that they could be taught in corporations. By the 1970s the reformation in business schools had begun to wain and modern business education, with its tolerance of excesses, was born in the 1980s.

No one would advocate repeating either the Great Depression or global conflict to restore an emphasis on appropriate managerial or business behavior, but the current attacks on the excesses of modern capitalism can be pointed out with references to the consequences of indifferent behavior and the pursuit of personal gain at the expense of others. At the moment, it appears that there are only a few professors in business schools that grasp the full extent of the 
consequences embedded in a continuation of current practices and are prepared to speak out against them.

PA: I see three ways in which we can help rather than impede the change we need so urgently.

First, in our research, we can recommit to ensuring that our scholarship addresses the big issues - rather than aiming at accumulating as many A-level journal publications as possible (RRBM, 2020).

Second, in our education activities, we should be doing more to sensitize future managers to the tensions and dilemmas they will face at work and in life, and offer them a range of perspectives that can help them make sense of those tensions. Business school should not only "train"—-transmit technical knowhow_but also "educate" — equip our students to deal constructively with the tensions that flow from accountability to multiple stakeholders. If some of our colleagues want to preach market fundamentalism, that should not deter others from offering a wider range of interpretive lenses (Adler, 2015).

Finally, in the governance of our business schools, we could broaden the range of stakeholders represented on our governing or advising boards and councils. At the moment, our institutions seem oriented almost exclusively to the big corporations and accounting and consulting firms who recruit our graduates and to the donors who support this orientation. If we included representatives of the local community, faculty, staff, students, and local government in these forums, we would be encouraged to broaden our educational and research mission along the lines I've just suggested.

CF: Management theory, business administration and economic science generally should be re-embedded into their broader interdisciplinary context and historic origin, which is political economy and philosophy. Adam Smith was a moral philosopher. A good economist isan ethicist, ecologist, psychologist, gender expert, a political scientist and democracy expert. Then, heading for more complex and holistic goal sets would be a natural consequence, and finance, money, and capital could be identified as means to serve higher and more important goals and values.

They would transmit alternative views of organizations, with a purpose instead of a financial bottom line, as "evolutionary organisms" instead of linear projects, and as a space of cocreation of equal humans in which every person contributes according to her or his capabilities, 
every person takes over specific responsibilities, and every person has a say in the whole and not only in the area where she or he is working directly.

They would also transmit innovative skills from emotional competence, appreciative communication, moderation skills, efficient decision-taking methods, and listening leadership from their hearts.

RS: We need to start with the idea of business as a noble vocation, that is rooted in a sacred obligation to truly take care of each other by meeting our real needs. We need to lead with the idea of serving others, meeting the real needs, creating value for them, whether it be customers, employees, suppliers, communities, society or the environment. We need to craft business models that enable us to realize our self-interest by doing those things in efficient and effective ways.

CHW: Business schools have an extremely important role in helping to challenge or reinforce dominant ways of thinking in business. Imagine that a business school starts from the premise that the purpose of a business is to benefit society and respect people. Then the question is what kind of a leader you need to become to stay true to such a purpose. The answer is a combination of competence and character. You need all the competencies traditionally taught. But if we think of a purpose-led business as a human system, what also matters is the development of character, as this shapes behavior and judgement. This would place a high emphasis on selfawareness and the cultivation of courage, honesty, vulnerability and generosity through experiential learning. It would also place a strong emphasis on an understanding of the quest for personal meaning and the quality of relationships that the business exists to help create, and which are also the basis of its long-term success.

\section{Reflections and Conclusion}

Our interviewees share a common theme in suggesting that the crisis of market capitalism has arisen largely because of an inversion of means and ends. In this perverse reversal of ontology, contemporary market capitalism assumes that humanity is understood to serve the interests of business, when, in fact, market capitalism ought to be an institutional tool devoted to serving the interests of humanity. Business schools, therefore, need to reduce their emphasis on how to make 
businesses more rational and efficient and instead focus on how they can help address more fundamental questions of the human condition.

Capitalism is an institution premised on the logic of using scientific and formal-procedural rationality to solve fundamental challenges for human survival - how to feed billions of people, how to cure devastating diseases, and how to impose structure and legal order on tumultuous social groups. A variety of organizational forms have emerged to address these pressing issues - the modern nation-state, the corporate organizational form, professional expertise - all of which are embedded in an ideology of progressive capitalism in which individual agency and choice are the ultimate measures of success. But, as Max Weber observed nearly a century ago, the promise of individual agency and choice created by rationality comes at the price of our humanity. In making our world more calculable and predictable, more efficient and bureaucratic, we substituting our substantive value-rationality (Wertrationalität) for formal procedural rationality (Zweckrationalität). Capitalism has adopted the form and structure, but not the substance, of what it means to be human.

Business schools, particularly elite US business schools, are the cathedrals of market capitalism and one common theme from our interviewees is that, just as capitalism needs to reembrace fundamental aspects of humanism, so too must business schools relax their obsession with profits, efficiency, competition, and the inherent supremacy of rational calculability. This road, Weber (1946, p. 389) observed, leads to disenchantment or "...the knowledge or belief...that there are no mysterious incalculable forces that come into play, but rather that one can master all things by calculation." But, once the material challenges of human existence are met, we must be careful to avoid the artificial substitution of the means and ends of capitalism. Market principles may offer valid answers to the most efficient means of organizing and distribution resources, we 
must be careful that the machine by which this allocation occurs, does not become an ontological value in and of itself. As John Kenneth Galbraith (2001, p. 429) noted, "One cannot defend production as satisfying wants if that production creates the wants".

We see this means-ends value confusion play out in the current COVID-19 crises where the nation-states that have benefited the most from capitalist ideology find themselves struggling to contain a virus because they must calculate the relative value of loss of life against the loss of economic productivity. The citizenry, by contrast, uses the logic of consumer choice to justify their right to endanger others and maintain their taken-for-granted routines of economic activity. For many, the logic of economic rationality trumps all other forms of reason, including scientific rationality. Business schools have much to answer for in this perverse reversal of ends and means, where we have been justifiably criticized for valorizing the individualistic and self-interested aspects of human nature and ignoring our counterbalancing propensity for altruism, ethics, and collectivism (Khurana, 2017).

The COVID-19 crisis has provided us with what Karl Weick (1993, p. 633) has termed a cosmological episode, an event where "people suddenly and deeply feel that the universe is no longer a rational, orderly system. What makes such an episode so shattering is that both the sense of what is occurring and the means to rebuild that sense collapse together." As devastating as cosmological episodes can be, they also offer the insight that occurs when the institutional fabric of society is torn open and, for a brief moment in time, we have the opportunity to see and critically re-evaluate the ontological assumptions upon which our core institutions have been built. Our interviews reveal that the core institutions of capitalism, as exemplified by elite North American business schools, have lost their connection with fundamental values of the human condition. We have unquestioningly accepted faulty ontological assumptions from economic theory in which the 
human condition is defined by guile, self-interest, and laziness. But we now have the opportunity to re-discover the ontological assumptions of the business organization, the business school and the image of the manager, not in the image of a Spartan warrior, but rather in the image of the Athenian citizen (Murcia, et al., 2018). We need to re-think and go beyond the limited assumptions of calculative rationality and individual self-interest to reach the deeper ontological assumptions of practical rationality and harmonious heterogeneous motivation (Rocha and Ghoshal, 2006). More critically, we need to recognize that we, as academic purveyors of management knowledge, must acknowledge our role in creating and maintaining the prevailing ideology and affirm our commitment to greater reflexivity in our pedagogy and our scholarship.

We conclude this article with four sets of questions designed to provoke our assumptions and our research agendas to embrace a new vision for capitalism and the role of management education.

At the societal level: How can we reform the assumptive primacy of economic success over social and humanitarian wellbeing? How does the existence of specific institutional networks such as the UN Global Compact for Businesses or the Principles for Responsible Management Education contribute to more meaningful and more humanitarian organizations? What more can be done to better integrate the collective interests of humanity with the institutional tools of global capitalism?

At the firm level: How do we make corporations serve the interests of their stakeholders? How can we reform the narrow and essentialist assumptions of human behavior that have driven our models of corporate governance? Should the purpose of the firm go beyond wealth creation?

At the level of individual entrepreneurs and managers: What is responsible leadership? How do responsible leaders create social value? What are the limits to wealth creation? 
At the level of the business school: What is our role in redefining the assumptions of capitalism? How can we introduce an ethos of humanitarianism into management education? Is our mission to create markets with optimal Pareto efficiency or to create barriers that encourage the individual accumulation of wealth? How do we fulfill our vision of the Academy of Management to "inspire and enable a better world" (Adler, 2014)?

We hope that these interviews motivate the reader to unleash their power to create managers, leaders, and organizations that promote a more humane world, that encourage our students to ask fundamental questions about the nature of business and society - what is a virtuous corporation? A moral consumer? A good job? Wise decision making? In this way, "we can help a new generation see that the field of management can be an exciting, worthwhile, and honourable profession" (Ghoshal, 2005, p. 350). 


\section{REFERENCES}

Adler, P. S. (2014). Capitalism in question. Journal of Management Inquiry, 23(2), 206-209.

Adler, P. S. (2016). 2015 Presidential address: Our teaching mission. Academy of Management Review, 41(2), 185-195.

Augier, M., \& March, J. G. (2007). The pursuit of relevance in management education. California Management Review, 49(3), 129-146.

Bennis, W. G., \& O'Toole, J. (2005). How business schools have lost their way. Harvard Business Review, 83(5), 96-104.

Collins, C. J., Hanges, P. J., \& Locke, E. A. 2004. The relationship of achievement motivation to entrepreneurial behavior: A meta-analysis. Human Performance, 17(1): 95-117.

Friedman, M. (1970). A Friedman doctrine: The social responsibility of business is to increase its profits. The New York Times Magazine, 13(1970), 32-33.

Galbraith, J.K. (2001). The dependence effect. Pp. 429-434 in Miller, D. (Ed.), Consumption: Theory and Issues in the Study of Consumption. London: Routledge.

Ghoshal, S. (2005). Bad management theories are destroying good management practices. Academy of Management learning \& education, 4(1), 75-91.

Ghoshal, S. \& Moran, P. (2005), "Toward a Good Theory of Management" , Pp. in Birkinshaw, J. \& Piramal, G. (eds.), Sumantra Ghoshal on Management, Pearson Education Limited, Prentice Hall, New York.

Hall, P. A. (2015). Varieties of capitalism. Emerging Trends in the Social and Behavioral Sciences: An Interdisciplinary, Searchable, and Linkable Resource, 1-15.

Khurana, R. (2007). From higher aims to hired hands: The social transformation of American business schools and the unfulfilled promise of management as a profession. Princeton University Press.

Jensen, M. C., \& Meckling, W. H. (1976). Agency Costs and the Theory of the Firm. Journal of financial economics, 3(4), 305-360.

Murcia, M. J., Rocha, H. O., \& Birkinshaw, J. (2018). Business schools at the crossroads? A trip back from Sparta to Athens. Journal of Business Ethics, 150(2), 579-591

Pew Research Center. 2016. The state of American jobs. Washington DC.

Pfeffer, J. (2005). Why do bad management theories persist? A comment on Ghoshal. Academy of Management Learning \& Education, 4(1), 96-100. 
Porter, M. E. (2008). On competition. Harvard Business Press.

Rocha, H. O., \& Ghoshal, S. (2006). Beyond self-interest revisited. Journal of Management Studies, 43(3), 585-619.

RRBM. 2020. Responsible Research in Business and Management: https://www.rrbm.network/

Suddaby, R., Ganzin, M., \& Minkus, A. (2017). Craft, magic and the re-enchantment of the world. In Management Research (pp. 41-72). Routledge.

Wang, L., \& Murnighan, J. K. (2011). On greed. Academy of Management Annals, 5(1), 279-316.

Warren, R. (2002). The purpose-driven life: what on earth am I here for? Zondervan.

Weber, M. (1946). Science as a Vocation. In Science and the Quest for Reality (pp. 382-394). Palgrave Macmillan, London.

Weick, K. E. (1993). The collapse of sensemaking in organizations: The Mann Gulch disaster. Administrative Science Quarterly, 628-652.

Whitley, Richard, 1999: Divergent Capitalisms: The Social Structuring of Business Systems. Oxford: Oxford University Press. 